\title{
8 Spanish military documentation on the Civil War and the dictatorship as an instrument of legal reparations for the victims of the Franco regime
}

\author{
Henar Alonso Rodríguez
}

\section{The memory condemned}

More than 40 years after the end of the dictatorship in Spain, and more than 80 years after the end of the bloody war that gave rise to it, Spanish society has not yet completed that 'model' transition that has received so much praise in some respects. And it has not done so because it is precisely this transition that has prevented a desirable break with the previous regime in many aspects, one of the most important ones being the use of state-led violence against the so-called enemies of the regime, most of them citizens with political ideas contrary to those imposed by the victors of the Civil War. The political, social, and, above all, legal configuration of Spain's Transition, in a way, condemned this memory of the past to being forgotten, and this is also reflected in the handling of the documentation of Franco's institutions of repression in general, and of the military authorities, in particular. Subsequent attempts to remedy this situation, such as the enactment of the 2007 Historical Memory Law, have not achieved the desired objective of establishing a clear distinction between what the events were, as they occurred (history) and what each person or social group experienced (memory), resulting in

a phenomenon contrary to the memory of history, little and poorly known, but which brings together a large part of Spanish society, not necessarily of a conservative bent. It is not historical revisionism that has permeated society but rather a negative perception of this memory and of those who claim it as a necessity, accused of stirring up the past for obscure reasons; a negative integration, anchored in the development of the Transition up to our times, which has, in the end, forged a reality of conflicting memories, complex and contradictory, which still exhibits the effects of what was the longest dictatorship in Western Europe.

(Gomez Bravo, 2014)

This continuity, without any institutional breakdown of the institutions holding political and social control under the Franco regime, and their 


\section{Henar Alonso Rodríguez}

almost automatic transformation into fully democratic institutions under the Spanish Constitution of 1978, meant that practically all the documentation they produced, including information on state-led repression, remained for a lengthy period of time under the control and in the custody of these inherited institutions, frequently even under the very individuals responsible for the previous regime, without the need for their preservation, organization, description or access to them being adequately guaranteed.

This situation was compounded by the move, detailed in Article 2(e) and (f) of the 1977 Amnesty Act ${ }^{1}$ and still in force today, which extended this measure to 'crimes and offences that may have been committed by the authorities, officials and agents of public order, on the occasion of, and as a result of, the investigation and prosecution of acts included under this Law' and to 'offences committed by public officials and law enforcement officers against the exercise of the rights of persons', which is a de facto imposition of the duty to forget, to not demand responsibility, to not want to know, and to not want anyone to know (González Quintana, 2007, p. 3).

Numerous social organizations have attempted to challenge this situation, using the inapplicability of this Amnesty Act as a justification, because crimes against humanity are never subject to a statute of limitations and because they contravene the general principles of law recognised by the international community, and of those that defend universal jurisdiction, including Amnesty International, Human Rights Watch, the Fibgar Foundation, and others. Again in 2018, the first timid legislative steps were taken towards creating institutions of transitional justice in Spain, as could be deduced from two bills presented during the 12th term of democratic office in the Spanish Parliament. These were aimed at improving the Law on the Historical Memory in this area. ${ }^{2}$ However, due to the political volatility reigning in Spain over the course of 2019, it was not easy to ascertain whether or not these would finally be implemented in practice. The possible implementation of a Commission for Truth in Spain, or the recovery of the full applicability of Universal Jurisdiction in Spain, which was reduced after the reforms of the Judiciary's Organic Law in 2009 and 2014, in any case, implied the urgent need to implement an archival policy which would favour promoting document fonds related to Franco's repression. These could thus be used for reparations to victims, and, if possible, even to demand accountability from guilty parties, to definitively bring to an end this 'transition from amnesia' which has gone on far too long.

\section{The 'archival policies' of military documentation during the Civil War, the dictatorship, and the Spanish Transition: from the destruction of the memory to forgetting}

It is important to analyse how the military documentation produced during the Civil War, the Franco dictatorship, and the Transition was handled historically in order to be able to establish clear conclusions about the selfinterested use of archives, both for the legitimisation and/or delegitimisation 
of political systems - and for the persecution and/or concealment of crimes committed. Based on the premise that throughout the 20th century and even at the beginning of the 21st century, the military archives have been kept practically independent from the remainder of public administration archives (González Quintana, 2006, p. 120), it is also fundamental to review the way in which some of the most important of these archives have been compiled, and the circumstances which characterise them.

During the war, the military documentation amassed by the two armies was also used as a weapon of combat for purely military tasks, such as obtaining information about the enemy, as an object of propaganda, and, above all, as a justification for each side's own actions, as well as evidence of each side's charge against the enemy. Document seizures and requisitions were constant, especially on the part of Franco's rebel Nacionales, while the government of the Republic collected documents more for the purposes of compilation than inquisition.

We owe the first 'War Archive', as such, to an Order of the Republican Ministry of Public Instruction, which, in the Gazette of the Republic of 17 August $1937,{ }^{3}$ ordered that both public and private bodies collaborate in the compilation of printed material produced 'as a result of current events', for that War Archive.

With the background of a provision from the Propaganda and Press Delegation of the Madrid Defence Board (Junta Delegada de Defensa de Madrid), which ordered that one of the three copies of the graphic documentation that was subject to censorship should become 'the archive of the revolution', its purpose was mainly of a propagandistic nature, with little structure, temporary, and limited almost exclusively to printed publications. With more of a cultural and participatory slant, it was aimed at justifying the anti-fascist struggle. With the capture of Barcelona by Franco's troops, the documentation that formed part of that first 'War Archive' was requisitioned and seised, and a small part of it ended up in what is now the Document Centre of the Historical Memory (Centro Documental de la Memoria Histórica), which contained information on its operation and its custodians. The remainder, mainly the collection of publications and printed matter, never left the city and is now housed in the Pavilion of the Republic, in the University of Barcelona Library (Pastor Núñez, 2019).

Nevertheless, without a doubt, the best-known 'archives of the Civil War' are those that emerged from the enormous process of seizing and requisitioning documentation obtained from military units, public bodies and political and social republican organizations, and from private homes and those who were killed or captured by troops of the so-called national side. This documentation was to be continuously and intensively used by the dictatorship with two clear objectives:

- The legitimisation of the coup d'état, the region-by-region occupation of the Civil War as a 'liberating' action, the 'unrest' provoked by the Republic, and the exaltation of the figure of General Franco. 


\section{Henar Alonso Rodríguez}

- The persecution and repression of those defeated in the 'Campaign of the War of Liberation' and of those who opposed the subsequent 'National Movement', based on personal information obtained from that documentation.

To this end, in order to build and impose an 'official memory' and justify the persecution of the adversary, it was necessary to collect, select, organise, and describe in detail all the documentation that could be obtained.

The first orders to gather documentation came precisely from the Generalísimo's headquarters, the nerve centre during the entire length of the war, which handled both the ordinary tasks of assistance and advice to the military command and the extraordinary tasks of public order and social control of the areas occupied by Franco's army.

The Office of Information and Anti-Communist Propaganda (OIPA: Oficina de Información y Propaganda Anticomunista), the National Delegation of Special Services, focused particularly on the collection of documentation from secret and Masonic societies, and the Document Retrieval Service were all created consecutively to preserve the documentation gathered by military units as the fronts developed. Later, in the final stretch of the Civil War, the system of requisitioning and seizure of Republican documentation by Franco's troops was perfected, through the creation of the State Delegation for the Recovery of Documents, then dependent on the recently created Ministry of the Interior, but still directly subordinated to the military authorities through, once again, the Generalísimo's HQ (Espinosa Romero, and Rodríguez López, 2015, p. 133 and the following). In fact, the document fonds compiled by these institutions were sent to - and finally located in - Salamanca, the usual headquarters of the Generalísimo, and are the origin of today's General Archive of the Civil War housed in the Document Centre of the Historical Memory.

It was precisely from those headquarters, shortly after the end of the Civil War, that General Franco ordered the collection of his own military documentation and that of the Republican side, first by means of telegrams sent to the generals in charge of the two armies and then by issuing a general instruction with regulations for classification, arrangement, and forwarding of the documents by the different units to the 'Historical Archive of the Campaign', which was being set up in Madrid under the orders of Colonel of the General Staff, Eduardo Fuentes Cervera, at the headquarters of the then Central Library in Calle Mártires de Alcalá.

The instruction provided for the classification and ordering of documentation for both the Republican and National side, organised by organizations and military units, and arranged according to sections of the General Staff, with six divisions: organization, information, operations, services, cartography and miscellaneous. The instruction was completed with rules for forwarding documentation, both the documentation itself, suitably marked as 'National Documentation', and the documentation requisitioned 
by the units from the defeated People's Republican Army, marked as Red Documentation.

The creation of the Military History Service (SHM: Servicio Histórico Militar) a few months later, ${ }^{4}$ in the custody of the army's Central Staff, gave this newly opened organization a legitimacy and an organic structure that was to remain constant practically throughout the Franco period and which was mainly devoted to the enormous task of classifying and ordering all the documentation sent by the units, in line with the 1939 Instruction. ${ }^{5}$ Between 1939 and 1944, fonds taken from the archives of the State Delegation for the Recovery of Documents were transferred to the now strictly military 'Archive of the War of Liberation' (Espinosa Romero, and Rodríguez López, 2015, p. 141). It was also the Military History Service, adopting the same criteria, which organised and classified part of the collection of the Spanish Volunteer Division (Blue Division: División Azul), which included it within the so-called Archive of the War of Liberation, and also produced several document compilations with the material received entitled, 'Secretarial Work', 'Mine War', and some revealing 'Political Background of the Republic', among others.

Subsequently, during the dictatorship, documents of historical importance continued to be sent to this Military History Service, such as the socalled Ifni-Sahara Campaign and the History Commission for Equatorial Guinea. During the democracy, the 'Archive of the National Militia' was added to these document collections, with documentation from the former regional, provincial, county, and local militia headquarters and those of the Military Information and Police Service (SIPM: Servicio de Información y Policia Militar) which, since its dissolution in 1939, had remained in the Internal Information Section of the General Staff's Information Division. In 1994, all these holdings were transferred, giving a definitive identity to the General Military Archive of Avila (Alonso Rodríguez, 2012, p. 4).

What the two document volumes have in common is that they were compiled, selected, organised, and described in detail for the purpose they were intended for. Those that are currently housed in the Military General Archive of Avila constructed and disseminated the 'official memory', thus legitimising the coup d'état and the subsequent Civil War as a response to the 'excesses' of the Republic. This was achieved through the decontextualisation of the scant 'Red Documentation' which the military officers themselves requisitioned, choosing the version that best justified those excesses, with an exaggerated estimation of the extremely abundant 'National Documentation', which praised the 'liberation' of the military occupation by the national forces, highlighting, moreover, the figure of the dictator by including among that documentation the documents from the Generalisimo's own Headquarters (Rial Quintela, 2017).

The documentation that remained in Salamanca, managed from 1944 by the National Delegation of Document Services under the Government Presidency, was used as a source of information on the military, political, and 
social background required by both ordinary jurisdiction and the military courts or the special courts for Repression of Freemasonry and Communism and that of Political Liability, for the information services of the general staff of the three armies and the Guardia Civil, and also for the General Directorate for Security, in charge of public order and which the much-feared Political-Social Brigade reported to. So, these served as separate elements of conviction to be used against the 'enemies of the regime' in each and every repression and weeding procedure to which they were subjected, whether of a criminal, economic, or administrative nature (Espinosa Romero and Rodríguez López, 2015, p. 147).

It is therefore essential to emphasise the real importance of the selfinterested handling of this documentation, of that 'archival policy' applied during the Franco regime, aimed at 'destroying the memory' of what the Republic was and what it meant, because, even today, both access to the archives and particularly the interpretation of these to a great extent determine their possible usefulness as instruments for legal and moral reparations for the victims of human rights violations during that period.

Another common characteristic of the two archives cited is that access to the documents was very restricted, practically limited to internal users: military historians, almost exclusively in the Military History Service, and legal, military, and administrative personnel in Salamanca. With the arrival of democracy and the suppression of the National Delegation of Document Services, the decision by the first government elected by ballot box was that its collections should be integrated within the National History Archive, at that time termed the 'Civil War Section', even though they remained in Salamanca. Precisely, this decision was what enabled the collection to be opened up to research for historical purposes. Similarly, and now after the promulgation of the 1978 Constitution, whose Article 105(b) established the right to access the archives and public records, the Military History Service also began to receive civilian researchers. However, in neither case was there any question of allowing access to the documentation for the purposes of historical research.

At no time was the possibility of using this access to analyse the potential of this documentation to ascertain the functioning of the state's repressive organizations during the dictatorship, nor the names of those responsible, nor to assert the rights to reparations of the victims of human rights violations (González Quintana, 2006, p. 136). The Civil War and the Dictatorship were already history; a history that, at last, any interested party could investigate and write about, but nothing more than that: a history, moreover, based on document holdings which were subjected to self-interested archive treatment, and which distanced them from an objective and impartial view of real events, and which, moreover, continued to be managed by the same people and the same institutions as in the previous regime, with hardly any changes. This permitted the dissemination of this 'alternative memory', which the Franco regime constructed at the time, to then be 
extended over time, significantly reducing the possibility of making use of this documentation for decades, for the purposes of reparations.

\section{The summary trials of military justice during the Civil War and the Franco regime: possibilities of applying an archival policy for the democratic memory}

The reaffirmation of this reality can be found, precisely, in the 1998 Regulations on Military Archives (RAM ${ }^{6}$ : Reglamento de Archivos Militares), which created the Defence Archive System and regulated the technical procedures and minimum material and personnel requirements needed by the military authorities to take responsibility for its document heritage. This regulation is highly specific in establishing the regulations on citizen access to the use of military documents, given the special sensitivity of the information contained in some of the document collections they hold. These RAM regulations recognise the right of free access with the typical limitations of state security and the right to the protection of the honour and privacy of individuals; however, it establishes the need to make public all the series excluded for those reasons and allows access to be requested. The Military Archives Regulations and this general system of access apply to all the collections managed by Military Archives except, as laid down in its Third Additional Provision, the documentation of the Military Court and Tribunal Archives. ${ }^{7}$ Consequently, all documentation produced by the military jurisdiction is outside the RAM, including one of the main sources for the study of the repression of the Franco regime, the so-called Summary Procedures. This abandonment of Military Justice archives to their fate meant that for decades this documentation was still held in the archives of the organizations that had produced them, although due to their age and disuse, they must have been transferred to general or historical archives, under the responsibility of a limited number of personnel in unsuitable facilities. These circumstances, of course, made it very difficult for researchers or those implicated by them to gain access.

The Historical Memory Law of $2007^{8}$ is a turning point in that it specifically mentioned the illegitimacy of all the courts which had been responsible for the repression during the Dictatorship, specifically including the War Councils, and their sentences and sanctions (Article 2), while at the same time guaranteeing the right of access to all public and private archives which contained documentation on the Civil War and the Dictatorship (Article 22). Under these provisions, two years later, the Regulations on Military Court Archives ${ }^{9}$ were finally enacted, a matter which, as in the case of the RAM, had been left pending in the Royal Decree of $2003^{10}$ on the modernisation of court archives.

An essential tool for accessing these holdings was the Guide to locating Court Proceedings initiated by the Military Justice system after the Civil War and during the Franco regime (Guía para la localización de Procedimientos 


\section{Henar Alonso Rodríguez}

Judiciales incoados por la Justicia Militar a raíz de la Guerra Civil y durante la etapa Franquista), ${ }^{11}$ produced in October 2015 by the technical staff at the Ministry of Defence. It describes both the physical location of each of the archives which contain these cases and the system for access to each of them: free and unrestricted if the holdings have already been transferred to general and historical archives, and upon request for authorisation from the military court authorities responsible for the custody of archives which have not yet been transferred. It also explains the share-out of the cases between the three armies (land, sea and air) and the current military court set-up, also assisting in the regional location of cases by the province where they were held, accompanied by a map of the regional organization of Military Justice, which can be consulted on the Ministry of Defence's Memoria Histórica website. ${ }^{12}$

As the Location Guide itself indicates, access to documentation for consultation purposes requires the prior authorisation of the military court authority responsible for its custody, except in cases where, in practice, it has been opened, on becoming part of the two military history archives that currently houses it: the Air Force History Archive, in Villaviciosa de Odón, and the most recent of the military archives created - the General and Historical Defence Archives - in Madrid. The first contains the court holdings produced by the Spanish Airforce's Central Jurisdiction, and the second, those of the First Regional Military Court. In both cases, there are name indexes and inventories of the court cases and purification dossiers, which enable location of the documentation through the names and surnames of the interested parties. ${ }^{13}$ However, the most important part of the summary trials is still in the possession of the auditors and rapporteurs of the Territorial Military Tribunals (TMT), in some cases deposited in appropriate facilities, and the investigations, searches, and organizational work on this documentation benefit from the support of the archivists of the Defence Archive System (North-west, Pyrenean, and Ceuta Intermediate Military Archives, in the case of the Spanish army; the Naval Archives of San Fernando, the Canary Islands, Cartagena, and Ferrol; and the Central Archive of the Armada Headquarters). In other cases, however, these records either lack adequate archive management and public handling, because they remain in the hands of the corresponding military court authorities, or have no opportunity for use as they are located in other military installations, constituting mere document stores that could hardly be considered archives as such.

The summary procedures are of vital importance for the implementation of legal reparations for the victims of repression under the Franco regime. And this is due to the fact that the validity of the military jurisdiction typical of wartime was extended beyond the armed conflict itself, even reaching the commencement of the Transition. This was also the case because this evidence is a faithful reflection of the generalised repression used as a system of social purging, together with maximum speed of processing and 
scarcely any procedural guarantees. Defence was almost testimonial, when not directly distorted, provoking extremely harsh sentences of an exemplary nature, which were usually applied to both ideological behaviour - qualified as crimes of treason, sedition, and aiding rebellion - and those acts which were described as common crimes: robbery, kidnapping, theft, banditry, sabotage, etc. (Rial Quintela, 2017). Therefore, the summary proceedings, due to their special characteristics, make up a document type that may contain data as relevant to processes of legal redress as the actual names of each and every person involved in the case, both the defendants themselves and the public officials and witnesses who intervened in each phase of the proceedings. Furthermore, from their reading, it is also possible to extract relevant information about the political and social circumstances that gave rise to the crimes being tried, above all based on witness testimonies, and the literal nature of arrest and search reports, cross-examinations, etc.

A clear example of the potential of summary proceedings as instruments of legal reparation for the victims of the Franco regime can be found in the decision taken by the Catalonian Regional Government (Generalitat de Catalunya), through its 2017 Legal Reparations Act ${ }^{14}$ for the Victims of the Franco regime. Its sole article declares the courts of the War Audit of the Army of Occupation as illegal. This was subsequently the War Audit of the IV Military Region, which acted in Catalonia from April 1938 to December 1978, 'declaring null and void all the sentences and resolutions of the cases instructed by war councils dictated by political causes' in the territories of the four Catalonian provinces. The real effectiveness of this regulation is completed with the authorisation to the National Archive of Catalonia to draw up and make public 'a list of proceedings conducted and sentences adopted' during this period 'in which the case number, the natural or legal person charged, and the sentence imposed are recorded' (First Final Provision). This 'list' is the final result of a complete archive management process, undertaken following a collaboration agreement between the Catalonian regional government, the Generalitat de Catalunya, and the Ministry of Defence, in which several archivists participated over a period of almost ten years. This process is described in detail and explained in the specific section of the project on the website of the Arxiu Nacional de Catalunya. ${ }^{15}$

The law which ordered the publication of what, in principle, is an instrument of description implied that this inventory was given legal validity in order to achieve the aim pursued, which was none other than to issue individualised certificates declaring, on the part of the Catalonian regional government's Department of Justice, the nullity of the sentences and resolutions of the repressive bodies of the Franco dictatorship. It amounted to nothing more than this but also nothing less than legally restoring the dignity that the victims had never lost - but which up till that point no administration had given them recognition for.

It is therefore possible to reuse the documentation produced by the institutions responsible for political and social repression during the Franco 
regime, for the purposes of reparations. But to do so, it is also necessary to recognise and break with the 'archival privileges' which the dictatorship applied to this documentation, especially that of courts, and which affect its identification, description, and long-term management. The example of the summary procedures is clear in this regard (Rial Quintela, 2018):

- During the war and the dictatorship, this denomination of 'summary trials' replaced the traditional 'Cases Section' (Sección de Causas) which encompassed the documentation produced by the military jurisdiction until then, in archival terms. This reflects its extension as a means of repression of the population, both military and civilian.

- From 1936 onwards, none of the documentation produced by military jurisdiction was transferred to the history archives. This remained intentionally in the custody of the military governments and the captain's general offices, exclusively at the disposal of the courts in order to monitor court cases beyond the sentence stage.

- The description tools needed to manage the enormous volume of documentation produced by the extensive structure of military justice were generally reduced to files ordered alphabetically by the names of the accused, with the topographical reference to the docket or file on the corresponding case, undoubtedly facilitating the routine management of a court, but limiting the possibilities of subsequent more in-depth historical research.

We must, then, move towards reparations as regards all these circumstances, and evaluate the possibility of giving new meaning to the part of the military justice holdings which corresponds to the period of the Civil War and the dictatorship as court holdings of the repression of the Franco regime, differentiating them from the rest of the military court holdings. It would also be necessary to ensure that the Single Transitional Provision (Disposición Transitoria Única) of the TMTs were complied with and that the custody of these court files from the period of the repression under Franco were transferred from the TMT to the general and historical archives, where they could be freely accessed without the need for authorisation from military auditors. Finally, with regard to the description, this should be extended, in those archives and by appropriate archive staff, and include all the data which could be extracted from the complete content of the documents, because this would enable a form of reparation based on the recovery of all the information on what actually occurred at that time. This goes beyond what the regime at the time wished to conceal or highlight. Thus, truth, justice, and reparations could be achieved through the application of an archive policy aimed at this objective.

The possibility that measures of this type could be applied to the rest of the military court procedures throughout the national territory would require, in addition to an indispensable political will, the extension of 
archive policies on the democratic memory, following the approach set out by the 'Basic Principles on the Role of Archivists and Records Managers in the Defence of Human Rights', a document produced by the International Council on Archives Working Group on Human Rights, ${ }^{16}$ aimed at preserving the collective memory and avoiding the emergence of revisionist and denialist theses on past historical episodes in which human rights violations were committed. However, this necessarily implies a commitment to maintain over time the human and material resources required to achieve this objective, thus reversing the permanent lack of resources, both in Spain's Defence Archives, as a whole, and in the rest of the archives of Spain's General Administration and those of other public or private bodies, because many of these may contain document collections related to human rights violations, thus guaranteeing the 'duty to preserve the memory'. This is set out in the third point of the UN High Commission for Human Rights: Updated Set of principles for the protection and promotion of human rights through action to combat impunity. ${ }^{17}$

\section{Notes}

1 Act 46/1977 of 15 October, on Amnesty (BOE-A-1977-24937).

2 Bill 22/000157 for the reform of Act 52/2007, of 26 December, by which rights are recognised and extended and measures are established in favour of those who suffered persecution or violence during the Civil War and the dictatorship, in the Boletin Oficial de las Cortes Generales (official government gazette), 190-1 of 22/12/2017, and Bill 122/000278 of Integrated Law on the Democratic Memory, and recognition of and reparations for the victims of the Franco regime and the Transition in the Boletin Oficial de las Cortes Generales, 317-1 of $15 / 10 / 2018$.

3 Order of the Ministry of Public Instruction and Health, giving instructions for the State, Provincial, and Municipal bodies, as well as those of a private nature, to provide documentary information and a bibliography of the transformation that has taken place in Spanish society as a result of current events, in accordance with the instructions inserted (BOE-B-1937-23951).

4 Order of the Ministry for the Armed Forces of 8 November 1939, creating the Military History Service (BOE-A-1939-12814).

5 A copy of this can be found in the General Military Archives of Avila: AGMAV, C. 1386,39 .

6 Royal Decree 2598/1998 of 4 December 1998, approving the Regulations on Military Archives (BOE-A-19989-29347).

7 Third Additional Provision of the RAM: 'These Regulations shall not apply to the Archives of the Military Courts and Tribunals, without prejudice to the study being undertaken to adapt the principles of these Regulations to those archives'.

8 Act 57/2007 of 26th December 2007, which recognises and extends rights and establishes measures in favour of those who suffered persecution or violence during the Civil War and the Dictatorship (BOE-A-2007-22296).

9 Royal Decree 1816/2009, of 27 November, approving the Regulations of the Military Justice Archives (BOE-A-2010-593).

10 Royal Decree 937/2003, of 18 July 2003, on the modernisation of the archives (BOE-A-2003-15237). 


\section{Henar Alonso Rodríguez}

11 Guide to Locating Legal Proceedings Initiated by Military Justice after the Civil War and during the Franco regime [Online] (Guía para la localización de Procedimientos Judiciales incoados por la Justicia Militar a raíz de la Guerra Civil y durante la etapa Franquista). Available at https://patrimoniocultural.defensa.gob. es/sites/default/files/2017-02/Gu \% C3\%ADa \%20Localisaci\% C3\%B3n \% 20 Fondos\%20Judiciales_OCT_2015.pdf, accessed 20 February 2019.

12 This interactive map is available at: https://www.defensa.gob.es/memoriahistorica/ a_militares_guia.html

13 The Historical Archive of the Spanish Air Force has two inventories on cases of Military Justice against military personnel who fought in the Republican Aviation Force during the Civil War (1936-1945), one containing court cases and the other consisting of files on purges of civilian personnel. The General and History Archives of Defence contain the list of holders of the TMT 1 files. The NorthWest Military Intermediate Archive has also published the list of holders of the cases initiated by TMT 4 in the provinces of León, Burgos, Soria, Salamanca, Zamora, Valladolid, and Álava. The inventories can be consulted in the sections corresponding to each of the archives through the web page patrimoniocultural. defensa.gob.es.

14 Autonomous Community of Catalonia Act 11/2017 of 4th July on legal reparations for the victims of Francoism (BOE-A-2017-8526).

15 Available at http://anc.gencat.cat/es/coneix/Projectes/procediments-judicials-militars/, accessed 21 February 2019.

16 Basic Principles on the Role of Archivists and Records Managers in the Defence of Human Rights, 2016, Principios básicos sobre el papel de archiveros $y$ gestores de documentos en la defensa de los derechos humanos, 2016 (online), International Council on Archives Working Group on Human Rights, Seoul, 20 February 2019.

17 Updated Set of Principles for the Protection and Promotion of Human Rights through Action to Combat Impunity, 2005 (online), Human Rights Commission (Conjunto de principios actualisado para la protección y promoción de los derechos humanos mediante la luch a contra la impunidad, 2005), E/CN.4/2005/102/ Add.1, 20 February 2019.

\section{Bibliography}

Alonso Rodríguez, Henar. 2012, "Organización de los fondos del Archivo General Militar de Ávila,” Boletín del Sistema Archivístico de la Defensa, vol. 22, pp. 3-12. Gómez Bravo, Gutmaro. 2014, Puig Antich. La transición inacabada. Madrid: Taurus.

González Quintana, Antonio. 2006, “Avatares de los fondos documentales militares y político-sociales españoles en el siglo XX," in: Los archivos españoles en el siglo XX: politicas archivísticas y producción bibliográfica. Madrid: ANABAD, pp. 118-149.

— 2007, "La política archivística del Gobierno español y la ausencia de gestión del pasado desde el comienzo de la transición," Hispania Nova: Revista de Historia Contemporánea, vol. 7, pp. 1-26 [online], accessed 10 February 2019.

Espinosa Romero, Jesús, and Rodríguez López, Sofía. 2015, “El Archivo de la Guerra Civil en Salamanca. De la Campaña a la Transición,” in: Paseo documental por el Madrid de antaño. Madrid: Universidad Complutense.

Pastor Núñez, Guillermo. 2019, "Un archivo vivo de la Guerra Civil Española," Kamchatka: Revista de análisis cultural, vol. 14, pp. 93-110, December. 
Rial Quintela, María del Carmen. 2018, "Desorientado los sumarísimos contra la mujer en la guerrilla antifranquista: aproximación a los archivos de la represión como cinta de Moebius," in: actas del II Seminario Mujeres investigadoras e investigación sobre mujeres en las Universidades Ibéricas. Salamanca, 2020 (not yet published).

- 2019, "Los fondos documentales del franquismo en los Archivos Militares," in: La alargada sombra del Franquismo. Naturaleza, mecanismos de pervivencia y huellas de la dictadura. Granada: Comares Historia, pp. 397-418. 